IMAFRONTE- $\mathrm{N}^{\mathrm{o}} 27.2020$, pp. 1-12

\title{
REUNIÓN DE MUJERES, REUNIÓN DE VIRTUDES. LA SALA DEL ESTRADO DEL PALACIO GUEVARA Y SU PROGRAMA ICONOGRÁFICO
}

\section{WOMEN'S MEETING, MEETING OF VIRTUES. THE GUEVARA'S PALACE SALA DEL ESTRADO AND ITS ICONOGRAPHICAL PROGRAM}

\author{
BEGOÑA ÁLVAREZ SEIJO
}

Universidad de Santiago de Compostela

\section{RESUMEN}

El presente trabajo pretende llevar a cabo un estudio del programa iconográfico realizado por el pintor lorquino Pedro Camacho Felizes de Alisén para la casa-palacio de los Guevara, situado en la ciudad de Lorca, para su sala del estrado; una veintena de lienzos de temática devocional, virtuosa y eminentemente femenina para un lugar de la vivienda reservado a la vida de las mujeres, cuyo análisis puede arrojar luz a la hora de comprender cómo era la educación de las nobles doncellas y las virtudes que debían encarnar en los albores del siglo XVIII en España.

PALABRAS CLAVE: Pintura, Barroco, Iconografía, Estudios de género, Palacio Guevara, Pedro Camacho.

\section{ABSTRACT}

The present work tries to carry out a study of the iconographical program depicted by Pedro Camacho Felizes de Alisén in the Guevara's palace, located in the city of Lorca, for its 'sala del estrado'; the analysis of twenty devotional, virtuous and with eminently feminine themes canvases, placed in a room reserved for women's daily lives, can shed light on the understanding of noble maiden's education and the virtues that they were to incarnate at the dawn of the eighteenth century in Spain.

KEY WORDS: Painting, Baroque, Iconography, Women studies, Guevara's Palace, Pedro Camacho. 



\section{AUTOR, PROMOTOR Y OBRA}

\subsection{PEDRO CAMACHO FELIZES DE ALISÉN}

Pedro Camacho Felizes de Alisén (1644-1716) es, sin duda, la figura lorquina más representativa de la segunda mitad del siglo XVII y, también, la última del Barroco en Murcia (Marco García, 2007-2008: 164). A pesar de que se ha calificado a este pintor como errático, de estilo inconsistente y tosco imitador de estampas, y de que sus obras hayan sido descritas como vulgares, con carencia valor artístico reseñable, su fama fue notable en la ciudad de Lorca en la segunda mitad del siglo XVII y los primeros años del siglo XVIII, recibiendo importantes encargos como la decoración de la casa-palacio de los Guevara, y ostentando una buena posición económica y social dentro de población local, con el consecuente reconocimiento de los personajes más notables de la misma, llegando a lograr la condición de hidalgo (Belda Navarro y Hernández Abadalejo, 2006: 293-294).

Nacido en Lorca en 1644, hijo de Juan Camacho y Catalina García Ramos, debió iniciar su formación como artista en la propia ciudad de Lorca al amparo de algún pintor local activo hacia el año $1658^{1}$ (Muñoz Clares, 1988). Esta primera etapa en la producción y estilo de Camacho, que se extiende desde 1658 hasta su estancia en Granada entre 1692 y 1693, se caracteriza por un estilo manierista bastante retardado, con gran influencia de los grabados flamencos, manejados por Camacho como medida para solventar sus problemas de composición (Hernández Abadalejo, 2006: 294). En sus obras de este periodo se aprecia un importante influjo de los pintores valencianos de finales del seiscientos, como Mateo Gilarte o Senén Vila, cuyo estilo había sido exportado a la región, ya que fue precisamente en la ciudad de Murcia donde estos pintores realizaron gran parte de su producción y en la cual también residió el pintor lorquino en la década de 1670 (Marco García, 2007-2008: 164). Camacho extendería su estancia en la capital hasta 1678, año en el que regresaría a Lorca definitivamente para contraer matrimonio con Doña María Maldonado, viuda del platero Gaspar López Quevedo (Muñoz Clares, 1988: 42-43). Esta primera etapa en el estilo de Camacho llegará a su culminación y mejor testimonio con el conjunto pictórico que realiza para don Juan de Guevara y su casapalacio de Lorca, para el que ejecuta alrededor de una veintena de lienzos en el año 1694 (Hernández Abadalejo, 2006: 295). Sin embargo, para comprender su evolución estilística, será clave ese año 1692 y su breve traslado a Granada, a donde acude con la intención de resolver un pleito en la Real Chancillería; será a partir de esta estadía en la ciudad de la Alhambra cuando comenzará a florecer una nueva etapa en el estilo y

\footnotetext{
${ }^{1}$ Se proponen nombres como los de Antonio Rojo o Juan Antonio Filibertos como responsables de la primera formación del pintor, pero la ausencia de noticias documentadas sobre la vida Camacho hasta la década de 1670, unido a su estilo ecléctico y peculiar, hace que resulte complicado dilucidar dónde y con quién se desarrolla dicha primera formación (Marco García, 2007-2008: 164).
} 
producción de Camacho, ya que allí entrará en contacto con la obra de artistas de la ciudad como Ambrosio Martínez, Esteban Rueda, Jerónimo Cieza, Alonso Cano, Juan Atanasio Bocanegra o Juan de Sevilla, y recibirá ecos más lejanos de la obra de Murillo, Zurbarán o Herrera el Mozo (Marco García, 2007-2008: 165; Hernández Abadalejo, 2006: 294). Mientras en sus obras anteriores a este periodo granadino se aprecia cierta torpeza compositiva, dependiente de modelos aprehendidos a través de su imitación de los maestros holandeses, y con un estilo demasiado arcaizante, tendente al claroscurismo y con una coloración muy apagada; a partir del contacto con las importantes corrientes pictóricas presentes en la Granada de la época, se aprecia una verdadera evolución en la obra de Camacho, demostrando un mayor dominio del dibujo, composiciones más rítmicas y dinámicas y con un colorido mucho más entendido, propio ya de un Barroco avanzado (Marco García, 2007-2008: 165).

\subsection{DON JUAN DE GUEVARA Y SU CASA SOLARIEGA}

Por su parte, don Juan de Guevara, perteneciente a una de las familias más destacadas de la hidalguía lorquina, fue el promotor y propietario de uno de los ejemplos más significativos de arquitectura civil barroca en todo el levante español y, sin duda, un arquetipo único en toda la región de Murcia: el palacio Guevara (Segado Bravo, 1991: 419).

Nacido en Lorca en 1656, contrae matrimonio con su prima hermana, Isabel Pérez de Meca, en el año 1679. De dicho matrimonio nacerán dos hijas: Beatriz, quien ingresa monja en el convento de Santa Ana y la Magdalena de la ciudad, falleciendo joven y célibe en 1709; y Juana Bautista, nacida en 1689, quien contrae matrimonio en 1716 con Juan Puxmarín Fajardo, hijo de la condesa de Montealegre y, por tanto, perteneciente a una de las familias de mayor abolengo de la nobleza murciana (Segado Bravo, 1991: 423). El mismo año del nacimiento de su hija menor, 1689, Juan de Guevara recibe el hábito de la Orden de Santiago, consiguiendo, de este modo, elevar su apellido a una de las cimas más altas a las que podía aspirar un hidalgo en la época (Muñoz Clares, 1994: 97). Seguramente este hecho fue uno de los detonantes para que don Juan decidiese emprender la construcción de su magnífica casa solariega en la ciudad de Lorca: una suntuosa y ostentosa proclama de su nueva condición y posición social (Pérez Sánchez, 1982; Muñoz Clares, 1994: 99). Las obras de esta opulenta construcción, erigida como monumento al honor de los Guevara, concluirían en el año 1694, año en la que precisamente se deben fechar los lienzos que Camacho ejecuta para su decoración. Sin embargo, se tiene constancia de que la familia Guevara continúa conviviendo en la residencia del padre de Isabel Pérez de Meca, es decir, del suegro de don Juan, hasta el año 1704 (Segado Bravo, 1991: 421). Probablemente este hecho fuese debido a que la vivienda aún no se encontraba en las condiciones idóneas para poder ser habitada, a pesar de que las obras de mayor envergadura hubiesen sido rematadas ocho años antes. Sea como fuere, la casapalacio de don Juan de Guevara, conocida hoy en día como "Casa de las Columnas" y considerada uno de los ejemplos más relevantes de casa solariega de la región, fue levantada como un maravilloso ejemplo de un despertar social hacia nuevas formas, consiguiendo que se consagrase el triunfo de un Barroco avanzado en Lorca y elevar a su promotor, más si cabe, dentro de la sociedad lorquina de la época, convirtiéndose, don Juan, en el hidalgo más recordado de la historia de la ciudad (Segado Bravo, 2012: 133; Belda Navarro, 1996: 21; Muñoz Clares, 1994: 98). De este modo, el conjunto arquitectónico de los Guevara declara la concesión de una gran relevancia a los elementos 
simbólicos que enorgullecen su linaje y las virtudes de los miembros de la familia, y así se demuestra en toda la ornamentación del palacio, desde la portada a la decoración interior (Belda Navarro, 1996: 23).

Un ejemplo de ello es precisamente el conjunto de lienzos que encarga a Camacho Felizes de Alisén, con quien el caballero santiaguista debió mantener una estrecha relación de amistad patrono-artista, pues la encomienda realizada al pintor lorquino traspasa los límites habituales de la demanda necesaria o habitual de obras ya que, como se ha apuntado anteriormente, consistió en más de una veintena de lienzos (Muñoz Clares, 1988: 145-146). Realizados en torno a 1694, la mayoría parece guardar cierta relación entre sí, pues a excepción de las representaciones de la Caída de Saulo y un Santiago en Batalla, realizados para el despacho de don Juan, junto con un Ecce Homo, una Virgen de la Soledad y un San Andrés atribuibles también a la técnica del artista lorquino, todos los demás fueron realizados para la denominada sala del estrado, presentan medidas similares entre sí y, la mayor parte, representan temas cuyo protagonismo recae en figuras femeninas. Gracias al estudio de los inventarios de la casa-palacio, fechados en 1710 y 1732, así como a la restauración que se ha llevado a cabo de los lienzos, donde se encontraron indicaciones de la mano del propio pintor de cómo debían ser colocados dentro de dicha sala, Muñoz Clares pudo realizar una reconstrucción en alzado de cómo debieron estar situados los lienzos ${ }^{2}$ y con ello tratar de llevar a cabo una lectura del programa iconográfico (Muñoz Clares, 1996).

De este modo, se tiene constancia de que en esta gran sala, divida a su vez en dos estancias conectadas por una puerta, denominadas por Camacho en las indicaciones de los bastidores como antesala y sala del estrado, se encontraban las siguientes representaciones: en la antesala, un gran lienzo que representa El incesto de las hijas de Lot, flanqueado por dos parejas de lienzos, de prácticamente el mismo tamaño dos a dos, una de San Joaquín y Santa Ana junto con una representación de Santa Clara y Santa Isabel, la primera sobre la puerta que conduce a la escalera y la segunda sobre la puerta de la propia antesala, y por otra pareja de obras, una que representa la Escala de Jacob y otra del Sueño de san José. Frente a estos lienzos, en la pared opuesta, se encontraban otros cuatro: tres de tamaño similar, La Caridad romana, Susana en el baño y La samaritana, separados estos dos últimos por un vano sobre el cual se encontraba una imagen de la Esperanza, de menor tamaño y que hoy en día no se conserva. Además, flanqueando el vano que miraba hacia el parador y presidiendo esta parte de la antesala, se hallaban las alegorías de la Fortaleza y la Templanza, prácticamente idénticas en sus medidas. Por su parte, en la sala contigua, denominada ya propiamente como estrado, estarían: flanqueando la puerta de acceso a la misma una Cabeza de San Atanasio y una Cabeza de San Juan Bautista, del mismo tamaño; un lienzo de Esther ante Asuero acompañado de un Éxtasis de santa Teresa, de grandes dimensiones, junto a las cuales se disponía una representación de La Magdalena, sobre una puerta y de menor tamaño; en la pared de enfrente destaca, por su gran envergadura, el Entierro de Cristo, flanqueado por dos vanos con vistas al jardín de la vivienda, sobre los que se encontraban dispuestas la Justicia y la Prudencia, de medidas similares a las otras dos virtudes cardinales situadas en la sala contigua; y por último, junto a la virtud de la Prudencia, un Ecce Homo, del que desconocemos las medidas exactas, pero en base a la reconstrucción realizada por

\footnotetext{
${ }^{2}$ Para la reconstrucción visual en planta y alzado véase Muñoz Clares, 1996: 125-127.
} 
Muñoz Clares debía ser de dimensiones parecidas a los Sueños de Jacob y san José.

\section{HISTORIA DEL ESPACIO: LA SALA DEL ESTRADO Y LAS REUNIONES DE MUJERES}

Antes de continuar analizando las pinturas de Camacho y las posibles lecturas que dichas iconografías podrían ofrecer como conjunto, se considera oportuno realizar un estudio previo del espacio para el que fueron concebidas, concretando los usos y significados del mismo.

La casa fue el espacio femenino por excelencia durante toda la Edad Moderna y, como tal, estaba impregnado de preceptos morales y convencionalismos sobre el papel que la mujer debía jugar dentro de la misma (Blasco Esquivias, 2017: 69). Dentro de los muros de la vivienda, la mujer se encontraba a salvo de las corruptelas y vicios a los que podía sucumbir en la realidad externa. Sin embargo, el confinamiento no consistía exclusivamente en permanecer en el interior del hogar, sino que, dentro del mismo, se señalaron, cuando era posible, unos espacios privados propiamente femeninos, diferenciados según ese uso exclusivo y excluyente, para que las mujeres desarrollasen sus labores en la intimidad y también para que se reuniesen con otras mujeres (Sobaler Seco, 2010: 151; Blasco Esquivias, 2017: 69-70). Uno de estos lugares era precisamente la sala del estrado.

Sebastián de Covarrubias en su Tesoro de la lengua española de 1611 lo define como el "lugar donde las señoras se sientan sobre cojines y reciben las visitas", definición que se mantiene también en el siglo XVIII, pues es descrito en el Diccionario de Autoridades, en 1720, como "el lugar o sala cubierta con alfombra y demás alhajas del estrado, donde se sientan las mujeres y reciben las visitas". Por lo tanto, el estrado se presenta como un habitáculo íntimo y social al mismo tiempo, estrictamente reservado para su uso por parte del género femenino. Sus orígenes en España se pueden rastrear desde la Edad Media, finales del siglo XII y principios del XIII, momento en el que fue adoptado por una clase noble cristiana que gustaba de imitar el fasto cordobés, ya que su nacimiento se cree ligado a una raíz presumiblemente islámica (Abad Zardoya, 2003: 376-377). Si bien en un principio era compartido por hombres y mujeres, se tiene constancia de que a partir del siglo XV se erige como un espacio esencialmente femenino, en el que las mujeres, descalzas y con las piernas cruzadas "a la morisca" o "a la turca", se sentaban sobre alfombras y cojines y recibían otras visitas femeninas, se dedicaban a la aguja, compartían lecturas edificantes o se entregaban a la oración (Sobaler Seco, 2010: 152). Sin embargo, fue durante los siglos XVI y XVII cuando el estrado experimentó un mayor desarrollo, llegando incluso a ser exportada esta idea de habitación de mujeres a las colonias americanas (Abad Zardoya, 2003: 378). De este modo, mientras el hombre atendía a sus invitados en su estudio o gabinete, la mujer quedaba confinada en el estrado (Urquízar Herrera, 2015: 224). Por lo tanto, esta sala cubierta con alfombras y alhajas, como la define Sebastián de Covarrubias, constituyó una parte esencial de la vivienda durante siglos en España, siendo el aposento femenino por excelencia, tanto en su vertiente pública, como era la recepción de visitas, como en la privada, pues también era el espacio que las mujeres ocupaban una vez terminaban con sus quehaceres domésticos, para descansar y reposar sin necesidad de abandonar la seguridad del hogar (Sobaler Seco, 
2010: 153). De este modo, el estrado, además de un espacio de sociabilidad femenina, se comprendía también como un espacio de tranquilidad para la mujer virtuosa, normalmente cercano a su alcoba y a los aposentos de sus hijos, donde se alejaba de los males y vicios del exterior y llevaba a cabo tareas asociadas al hecho mismo de ser mujer, como coser o rezar. Espacialmente, podía ocupar tanto una habitación entera como varias, o incluso estar incluido dentro de una sala amplia, destacándose visualmente mediante una tarima (Martínez Alcázar, 2011: 99).

Como explica Sobaler Seco, el estrado además de estar decorado con alfombras, cojines y alhajas solía estar presidido por imágenes religiosas de devoción, frecuentemente de la Virgen María, por ser un ejemplo de virtud femenina en todos sus estados (2010: 151). Pues, no se debe obviar ni olvidar, que a pesar del carácter doméstico y privado de la sala del estrado, se trataba de un ambiente de la vivienda expuesto al escrutinio y juicio de la mirada pública, por ser el área del hogar en la que las mujeres recibían a sus visitantes. En una época como la del Barroco español, con su férreo control de la moral social, fuertemente impregnada por los dogmas católicos, el papel de la mujer y las conductas femeninas, siempre supeditadas al cabeza de familia dentro de un sistema totalmente jerarquizado y cerrado, las apariencias tenían una importancia crucial a la hora de mantener la honra de un linaje de cara al resto de la sociedad, de cara a afirmar posiciones y establecer alianzas sociales (Sobaler Seco, 2010: 164). De este modo, era necesario que un espacio como el estrado se mostrase como un lugar que despertase admiración, por parte de sus visitantes, de los personajes que lo habitaban. De ahí que la decoración de la sala del estrado fuese motivo de esfuerzo para determinados sectores de la sociedad española de la época, buscando, por un lado, ostentación y estupor por parte del público que pudiese acceder al mismo y, por otro, educar y adoctrinar a las mujeres que lo habitaban, para que se presentasen a esas visitas como personificaciones mismas de las mujeres virtuosas que decoraban esos espacios. Pues no se debe obviar que, en los siglos del Barroco, las imágenes religiosas constituían uno de los principales medios a disposición de la población para mostrar y enaltecer tanto su condición social como la honra de los miembros de la familia y su inquebrantable sumisión a los postulados de la Iglesia, puesto que las representaciones pictóricas se veían como una de las armas más eficaces para llevar a cabo esta labor esta pedagógica y de propaganda, ya que las creencias de una persona o familia no eran algo privado, sino que se hacía alarde de las mismas como una ostentación de su fe y valores morales (Morera Villuendas, 2015: 1290). De ahí que este tipo de estancias, durante la Edad Moderna en España, fuesen decoradas mediante un discurso devocional que resaltase las virtudes femeninas de las mujeres que allí habitaban, destinado tanto al espectador que pudiese contemplarlo como a las propias mujeres de la casa, como recordatorio del sendero de rectitud que debían seguir si querían mantener la honra de su estirpe.

Precisamente, debido a que la sala del estrado se constituyó en los siglos XVI y XVII como el aposento femenino por excelencia, presente en multitud de hogares de diverso estrato social, como prácticamente todo lo que atañe a la mujer durante la Edad Moderna en España, el estrado también se vio normativizado, popularizándose todo un corpus literario sobre las conductas y virtudes que se debían mostrar en estos espacios. Pues como espacios situados en la intimidad del hogar, pero con acceso puntual del público debían regirse por las reglas del decoro y su estricto código de honor y respeto de los presupuestos morales imperantes. De las mujeres, tanto en un ámbito público como 
privado, se esperaba un comportamiento intachable, que se puede sintetizar en que debían actuar con orden y rectitud: ojos bajos, rostro sereno, silenciosas, castas, prudentes, templadas, honestas, justas y fuertes ante las tentaciones de los vicios; en definitiva, debían ser mujeres virtuosas y virtuoso debía ser su comportamiento en el estrado (Morera Villuendas, 2015: 1292). De este modo, todavía en el siglo XVIII existen obras como La virtud en el Estrado. Visitas juiciosas. Crítica espiritual escrita en 1739 por Don Antonio Ossorio de la Cadena, donde advierte de los peligros que sobrevuelan a las mujeres y la actitud que deben adoptar para preservar su nobleza y grandeza, que debe ser siempre virtuosa, pues "la mayor honra que pueden pretender, es, poner a los pies los vicios, y sobre su cabeza las virtudes" y deben esforzarse "en ser honestas, en estar retiradas de los hombres, en ser recatadas en sus ojos, que los demás ignoren de qué color son; en ser aplicadas en el trabajo y cuidadosas en el aprovechamiento de sus almas" (Ossorio de la Cadena, 1739: 192). Unos años más tarde, de 1789, nos encontramos con otra obra que habla de la virtud en el estrado titulada El Ceremonial de Estrados y crítica de visitas, donde, empleando un tono jocoso, su autor informa sobre los comportamientos femeninos adecuados para estas estancias y recalca que, aunque muchos han escrito sobre estas habitaciones de mujeres antes que él, la novedad de su obra reside precisamente en el matiz cómico y agudo que otorga a estas enseñanzas.

Por lo tanto, la sala del estrado no solo tenía una serie de características espaciales definidas dentro de la vivienda durante la Edad Moderna, sino que además se configuró un corpus teórico acerca de las conductas y actitudes que las mujeres debían adoptar dentro del mismo, es decir, existió una regulación de la moral en el estrado, siempre orientada al realce y fomento de la virtud femenina, que bien pudo afectar también a las imágenes devocionales ejecutadas para su adorno.

\section{EL PROGRAMA ICONOGRÁFICO: REUNIÓN DE VIRTUDES}

Retomando el programa iconográfico realizado por Pedro Camacho Felizes de Alisén para la casa-palacio de los Guevara en Lorca, como ya se ha indicado en los estudios previos que se han realizado de este conjunto pictórico, estas obras, al estar dispuestas decorando un espacio destinado al uso doméstico femenino, el estrado, podrían tener un afán educativo y moralizador de cara a la instrucción de las mujeres de la familia (Muñoz Clares, 1988: 146-147; Muñoz Clares, 1996: 123; Hernández Abadalejo, 2006: 295-296). Como bien ha apuntado Muñoz Clares, estamos ante un programa iconográfico en el que la mayoría de las representaciones siguen lo expresado por Palomino en $E l$ museo pictórico y Escala óptica como decoroso y adecuado para las habitaciones destinadas a las mujeres de la familia:

"Y si fuere el sitio, que se ha de pintar, habitación de señoras, debe huirse totalmente de las fábulas, buscando siempre asuntos nobles, decorosos, honestos y ejemplares. Para lo cual hay gran copia de mujeres ilustres en las sagradas letras: como una Esther, una Abigail, Débora, Jael, Micol, Judit, y otras muchas. Y de las letras humanas hay mujeres constantes y valerosas: como Cleopatra, Artemisa, Porcia, Lucrecia, etc. De las santas las Isabeles de Hungría, y Portugal, además de otras ejemplares matronas; exornando todo esto a trechos, o tramos configuras morales, significativas de las virtudes, que practicaron los héroes en aquellos actos, que allí se representan" (Palomino, 1947: 651).

Ejemplos que se corresponden con esa función educativa, la que suponía para las 
mujeres el mero hecho de que se representasen en sus aposentos figuras femeninas virtuosas, que enuncia las palabras de Palomino, los encontramos en el mismo Alcázar de Madrid, en el Salón de los Espejos, donde se disponía la serie de mujeres fuertes del Antiguo Testamento de Tintoretto, traída por Velázquez de Italia para Felipe IV en 1649, empleada como espacio de poder por la reina Mariana de Austria durante su regencia (García Hidalgo de Villena, 2017: 390-391; Álvarez Seijo, 2018: 199-120; Pascual Chenel, 2006); o en el famoso camarín dedicado a la Virgen de Guadalupe del monasterio de las Descalzas Reales de Madrid, un complejo programa iconográfico protagonizado por las mujeres fuertes del Viejo Testamento y la Inmaculada Concepción, emplazado en el claustro para prestigio de su promotora, Sor Ana Dorotea de Austria, y para la educación e inspiración de las monjas que allí residían (Álvarez Seijo, 2017-2018).

Sin embargo, y pese a que la intención pedagógica del programa creado por Camacho para Juan de Guevara es incuestionable, debido a lo anteriormente expuesto sobre las salas del estrado, su función y normativización, así como por la constante premisa de que debía ser un área de la vivienda que destacase las virtudes de las mujeres que allí vivían, creemos necesario precisar algunas cuestiones de su lectura como conjunto, puesto que, por un lado, algunas de las representaciones parecen no adecuarse al modelo propuesto por Palomino de mujer decorosa, honesta y ejemplar, y, por otro, debido a la especial situación del estrado dentro del resto de tipologías de habitaciones de mujeres por su doble naturaleza, privada y pública.

Comenzado por la denominada antesala en las inscripciones que Camacho realiza para la correcta colocación de los lienzos, en el conjunto de cinco cuadros presidido por la imagen de El incesto de las hijas de Lot, acompañado por las representaciones de Santa Clara y Santa Isabel, San Joaquín y Santa Ana, La Escala de Jacob y El Sueño de san José, nos encontramos que mientras que las representaciones de San José y Jacob, claramente relacionadas entre sí como pareja, representando la fortaleza y la templanza de dos hombres ante los designios de Dios, que se manifiesta a ambos a través del sueño, y la pareja de lienzos de San Joaquín y Santa Ana, imagen de un matrimonio ideal, fuerte y templado, que espera paciente y honestamente a que se cumplan sus anhelos de descendencia, y Santa Clara y Santa Isabel, dos mujeres que ofrecen su vida a Dios sin esperar nada a cambio, encarnación de la vida conventual y, por tanto, de otra de las formas de existencia aceptables para una mujer respetable, son representaciones devocionales en las que se exalta precisamente un comportamiento virtuoso sin sombra de duda, el lienzo de Lot y sus hijas, sin embargo, presenta mayores dificultades de lectura. A pesar de haber sido vista en ocasiones como una máxima del amor filial, por el sacrificio que realizan las hijas del buen Lot al creer que deben cometer el incesto para salvar a la humanidad, esta representación no siempre fue entendida del mismo en la época. Así lo expone José Barcia y Zambrano en su Despertador Christiano de 1693: "Allí sus hijas le embriagaron, y allí concibieron de su mismo padre, y de estos incestos horribles nacieron Moab y Amon, de que siguieron esas dos infertilisimas naciones. ¡Oh Lot! ¿Qué ha sido esto? ¿En Sodoma casto y en el monte incestuoso?” (304). Por su parte, Manuel Guevara y Ribera, en sus Oraciones varias consagradas a María nuestra Madre de Dios, y pecadores, dice: "Si fueres muger, atiende si eres tan curiosa como la muger de Lot, o tan ambiciosa de vanidad como sus hijas. Mira bien si tienes estos deseos, porque a raíz de estos deseos hallaron aquellos castigos" (1691: 284).

Por lo tanto, otra lectura plausible de esta representación podría ser el clave de 
advertencia, pues no importa la fortaleza del padre sino es imitada por sus hijas. Y lo mismo sucede con las representaciones de La Samaritana, Susana en el baño y La Caridad romana. Mientras la virtud de la fortaleza de esta última está fuera de todo resquicio de duda, al igual que ocurre con Susana, que se mantiene fuerte para preservar la virtud de su castidad, la figura de la Samaritana sería otra imagen de contraste, de aviso, pero que ofrece también la esperanza de la redención: "Nuestra Samaritana; primero pecadora; después penitente: primero meretriz, después santa: primero escandalosa; después exemplarisima: primero tropiezo, después edificadora de su Ciudad, a costa de los sudores y fatigas del Salvador" (Muniesa, 1615: 209). De ahí que, sobre el vano situado al lado del lienzo de La Samaritana, se situase la hoy perdida representación de La Esperanza, pues incluso una mujer pecadora y perdida como la Samaritana, gracias a su fe en Dios, encontró la virtud y con ella redención. Esta representación, junto con las de La Fortaleza y La Templanza, situadas flanqueando el vano que se abre en la pared que da hacia el parador, serían la guía y luz de esta antesala, pues por un lado son alegorías de las virtudes que se exaltan en muchas de las representaciones y, por otro, siempre colocadas sobre ventanas, arrojan luz para iluminar a aquellas que ejemplifican su pérdida con la esperanza de que se encuentre el camino de vuelta.

Lo mismo ocurre con la sala contigua, denominada por Camacho propiamente como el estrado. Aquí la Prudencia y la Justicia, cada una sobre una ventana que abre el espacio hacia el jardín, se personifican para iluminar las virtudes que se enaltecen en el resto de lienzos de la esta estancia. La prudente y justa Esther ante Asuero junto con el Extásis de santa Teresa, símbolo también de todas estas virtudes, acompañadas de la pequeña representación de la Magdalena penitente, imagen por excelencia del arrepentimiento y la posibilidad de redención ante las faltas, habiendo encontrado de nuevo, gracias a su fe, el sendero de la decencia. Por su parte, el enorme lienzo con la representación del Entierro de Cristo, podría verse como la imagen que sintetiza y enaltece todo el conjunto, pues simboliza no solo todas las virtudes sino que también evoca el sacrificio que Cristo realiza por la humanidad.

Por lo tanto, a pesar de que algunas de las representaciones se relacionan entre sí como pareja o pequeños conjuntos dentro la totalidad del programa, la miscelánea de temas representados, tan alejados algunos entre sí, tienen precisamente un punto en común: la exaltación de la virtud o lo que conlleva la pérdida de la misma. De este modo, estamos ante un programa iconográfico que podría encontrar su unión, precisamente, en las cuatro Virtudes Cardinales; a pesar de su pequeño tamaño respecto a otras de las representaciones, las imágenes de la Fortaleza, la Templanza, la Justicia y la Prudencia, fueron colocadas sobre los vanos que iluminaban el espacio, una posible metáfora de su carácter de guía del conjunto, y eran consideradas la fuente de la que emanaban todas las demás virtudes. Así lo expresa Sánchez Maldonado en su Agricultura alegórica o espiritual de 1603, que versa sobre cómo arrancar los vicios y resaltar las virtudes de las personas devotas y fieles a Dios:

"Porque el que es pobre de espíritu no es avaro: el que llora no se ensoberbece, sino antes es manso y pacífico: el que gime se humilla: el que es justo, no niega lo que le es dado para su uso, y para el común provecho de todos: el que usa de misericordia da de lo tiene, no busca ni toma lo ajeno, ni trata de engañar a su próximo. De tal manera que están las virtudes entretejidas y encadenadas las unas con las otras, que el que perfectamente tiene una tiene muchas: y el que más se esmerare y en más perfección tuviere una virtud, crea que ha de tener della mayor premio" (Sánchez Maldonado, 1603: 400). 
Por su parte, las representaciones que no se ajustan a este modelo de feminidad decorosa, honesta y ejemplar, como El incesto de las hijas de Lot o La Samaritana, pueden explicarse por ese mecanismo de contraposición de imágenes de exaltación de la virtud con otras en las que se evidencia su pérdida. Esta solución fue popular en la época, ya que se entendía que debían sacarse a la luz los fallos de los pecadores, revelar sus faltas, cometidas a causa de los vicios, como única forma de que pudiesen ser arrancadas $\mathrm{y}$, de este modo, conseguir, con su arrepentimiento, la salvación, personificada en la representación de la Esperanza:

"Para que en la tierra del corazón crezca el trigo de las virtudes también es necesario que entresaquemos las malas yerbas de los vicios y las malas inclinaciones que entre ellas nacen. De este modo, las plantas infructuosas se convierten en fructíferas y los pecadores se harán justos [...] En lugar del pecado y la maldad crecerá la justicia; en lugar de la temeridad, la fortaleza; en lugar de la ignorancia, la prudencia; en lugar de la deshonestidad, la templanza y en lugar de la idolatría el verdadero culto divino y reverencia" (Sánchez Maldonado, 1603: 433).

Ése era precisamente el poder de la pintura como arma discursiva durante la Edad Moderna: su capacidad de enseñar a los individuos en qué debían creer, cómo debían comportarse y qué roles debían asumir en la estructura social, a través tanto de representar el modelo positivo, que debía ser emulado, como el negativo, del que se buscaba la condena (Maravall, 1975; González Sánchez, 2017). Además, según lo expuesto anteriormente sobre la sala del estrado, sus usos y reglas, no se debe obviar que se trataba de un espacio para las mujeres de la casa, pero que también estaba sometido al escrutinio público, pues era el lugar en el que éstas recibían a sus visitantes. Por lo tanto, la educación de la mujer y las hijas de Don Juan de Guevara sería uno de los fines buscados a la hora de concebir el programa, pero también la idea de transmitir, a todo aquel que pudiese contemplarlo, que las señoras que habitaban esa casa-palacio eran mujeres ejemplares, virtuosas en todos sus estados. Ser, durante la Edad Moderna en España, era parecer, y parecer era, prácticamente, ser (Soria Mesa, 2009: 9); las apariencias eran vitales a la hora mantener el estatus de un linaje y, por ello, toda la decoración de los estrados, desde sus alhajas a las imágenes, se consideraba capital para reforzar el prestigio familiar, por lo que debe verse en el programa de Camacho, asimismo, la voluntad de constituirse como una forma de ostentación de la honra de la prosapia de los Guevara, de mostrar a sus espectadores lo inefable del comportamiento de todos sus miembros.

\section{CONCLUSIÓN}

En síntesis, se puede concluir que el programa realizado por Pedro Camacho Felizes de Alisén para Juan de Guevara y su casa-palacio de la localidad murciana de Lorca fue un conjunto con un protagonismo predominantemente femenino y dedicado al elogio de las mujeres de la familia, al mismo tiempo que funcionaba como una herramienta para su educación. Una veintena de lienzos realizados para un espacio concreto, con el que dialogan y al que se adaptan, pues cumplen con la idea de virtuosismo femenino que debía predominar en el estrado, área de la vivienda, pública e íntima al mismo tiempo, reservada al confinamiento femenino dentro del hogar, su lugar primigenio de reclusión.

En una época como la del Barroco español, donde la honra y prestigio significaban 
el triunfo o caída de una buena familia, la vida de las mujeres, siempre supeditadas a los mandatos y decisiones del cabeza de familia, estaba totalmente reglada y regulada; también en sus espacios de uso personal. De este modo, el pintor lorquino idea un programa donde la norma, la pauta, la marcan las virtudes que deben acompañar a las mujeres del hogar en todas sus decisiones y que, al mismo tiempo, transmite esa idea de ejemplaridad a toda aquella visita que pudiese contemplar el conjunto. Al fin y al cabo, ésa es la función principal por la que nace la tipología del estrado, el dar cobijo a las reuniones de mujeres, y ¿qué mejor decoración para un espacio de esas características que una reunión de virtudes?

\section{BIBLIOGRAFIA}

Anónimo (1789). El Ceremonial de Estrados y crítica de las visitas. Madrid: imprenta de Antonio Espinosa.

Abad Zardoya, C. (2003). El Estrado: continuidad de la herencia islámica en los interiores domésticos zaragozanos de las primeras cortes borbónicas. Artigrama, 18, 375-392.

Álvarez Seijo, B. (2017-2018). En-Clave de género: las mujeres fuertes del Antiguo Testamento en la Capilla de la Virgen de Guadalupe de las Descalzas Reales. Anuario del Departamento de Historia y Teoría del Arte, 29-30, 143-167.

Álvarez Seijo, B. (2018). Sebastián Herrera Barnuevo y las mujeres fuertes del Antiguo Testamento: un análisis de las pinturas perdidas de la capilla de Nuestra Señora del Buen Consejo de la Colegiata de San Isidro. En Patrimonio artístico y documental del Mundo Hispánico: de la Edad Media a la actualidad: nuevas perspectivas de estudio. León: Universidad de León, 117127.

Barcia y Zambrano, J. (1693). Despertador christiano. Madrid: por Juan García Infanzón.

Belda Navarro, C. (1996). Portivs Quam Foedari. Imafronte, 10, 21-40.

Belda Navarro, C.; Hernández Abadalejo, E. (2006). Arte en la región de Murcia: de la reconquista a la Ilustración. Murcia: Consejería de Educación y Cultura.

Blasco Esquivias, B. (2017). Vivir y convivir. Familia y Espacio doméstico en la Edad Moderna. En La (s) casa (s) en la Edad Moderna. Zaragoza: Instituto "Fernando El Católico", 65-92.

Covarrubias Orozco, Sebastián (1611). Tesoro de la lengua castellana, o española. Madrid: por Luis Sánchez, impresor del Rey.

García Hidalgo de Villena, C. (2017). El descubrimiento de Jacopo Tintoretto en la pintura barroca madrileña: el caso de Sebastián de Herrera Barnuevo. En El Barroco: universo de experiencias. Córdoba: Asociación Hurtado Izquierdo, 387-406.

González Sánchez, C. A. (2017). El espiritu de la imagen: Arte y religión en el mundo hispánico de la Contrarreforma. Madrid: Cátedra.

Maravall, A. (1975). La cultura del barroco. Análisis de una estructura histórica. Barcelona: Ariel.

Marco García, V. (2007-2008). Influencias de Alonso Cano en la obra del pintor lorquino Pedro Camacho Felizes de Alisén. A propósito de la Virgen del Rosario, obra inédita del Museo de Bellas Artes de Valencia. Imafronte, 19-20, 161-175.

Mártinez Alcazar, E. (2011). Los espacios públicos de la vivienda acomodada en el siglo XVII a partir de la documentación notarial de Murcia y Madrid. Atrio, 17, 91-102.

Morera Villuendas, A. (2015). Del Estrado al Gabinete. Privatización de la vida doméstica. En Comercio y Cultura en la Edad Moderna. Sevilla: Editorial Universidad de Sevilla, 1287-1299.

Muniesa, T. (1683). Quaresma quarta. Barcelona: por José López.

Muñoz Clares, M. (1988). El pintor Pedro Camacho Felizes de Alisén y su entorno artístico. Murcia: Academia Alfonso X "El Sabio", Ayuntamiento de Lorca.

Muñoz Clares, M. (1994). Sobre la construcción de la Casa-Guevara. Murgetana, 89, 97-114.

Muñoz Clares, M. (1996). El saco roto de la pintura religiosa. Imafronte, 11, 115-134. 
Ossorio de la Cadena, A. (1764). La virtud en el estrado. Visitas juiciosas. Madrid: imprenta de Andrés Ortega.

Palomino de Castro y Velasco, A. (1947). El museo pictórico y Escala óptica. Madrid: Ediciones Aguilar.

Pascual Chenel, A. (2006). Retórica del poder y persuasión política. Los retratos dobles de Carlos ii y Mariana de Austria. Goya: Revista de Arte, 331, 124- 145.

Pérez Sánchez, A. E. (1982). Presencia de Lorca en el arte español. En II Ciclo de Temas Lorquinos. Lorca: Editorial C.A.A.M.

Sánchez Maldonado, D. (1603). Agricultura alegórica o espiritual. Burgos: por Juan Bautista Vesaio.

Segado Bravo, P. (1991). Don Juan de Guevara y su casa-palacio de Lorca (Murcia), un prototipo de mentalidad barroca en el sureste español. En Actas del I Congreso Internacional do Barroco. Vol. II. Oporto, 419-449.

Segado Bravo, P. (2012). El patrimonio artístico y cultural de Lorca. En Patrimonio Cultural en España, VI. Patrimonio en riesgo: seísmos y bienes culturales. Madrid: Ministerio de Educación, Cultura y Deporte, 123-136.

Sobaler Seco, $\mathrm{M}^{\mathrm{a}}$. A. (2010). Espacios femeninos en la Castilla del Antiguo Régimen. Cultura material y sociabilidad en el estrado. En Portas Adentro: comer, vestir, habitar (ss. XVI-XIX). Coimbra: Imprensa da Universidade de Coimbra, 149-169.

Soria Mesa, E. (2009). Tomando nombres ajenos. La usurpación de apellidos como estrategia de ascenso social en el seno de la élite granadina durante la época moderna. En Las élites en la época moderna: la monarquía española, Vol. 1. Córdoba: Universidad de Córdoba, Servicio de publicaciones, 9-28.

Urquízar Herrera, A. (2015). Espacios sociales femeninos y promociones artísticas en la Edad Moderna. En Imágenes de poder en la Edad Moderna. Madrid: Editorial Universitaria Ramón Areces, 217-227. 